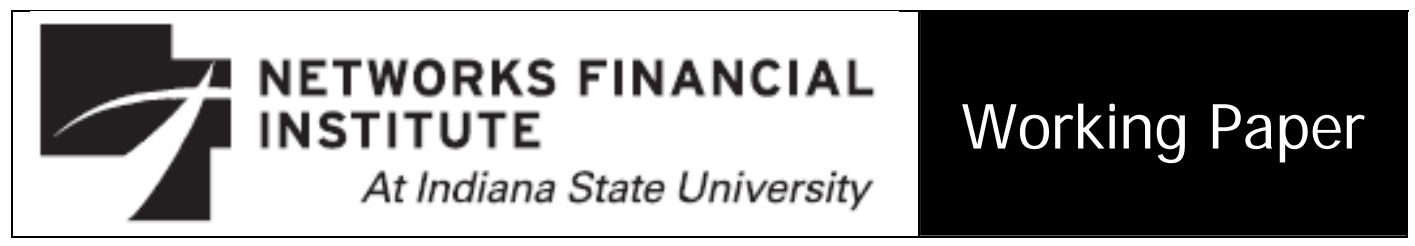

2011-WP-21b

August 2011; revised September 2011; revised February 2013

\title{
U.S. Monetary Policy in Disarray
}

\section{John A. Tatom}

Abstract: Monetary policy became more difficult to characterize during and after the mortgage foreclose and financial crises because of a shift to a new credit policy focused on private sector credit and that relies on traditional commercial banking strategies. The new credit policy broke the tight link that had existed between Fed credit and its effective monetary base, the monetary base that affects monetary aggregates. The Fed has adopted an exit strategy, but the discretionary powers that it followed remain in place as does a mistaken policy on the payment of interest on excess reserves.

About the Author: John A. Tatom is President of Thoroughbred Economics which provides research on global capital markets, the financial industry, macroeconomic performance and economic and regulatory policy issues. They also serve as a research consultancy for the insurance industry on financial regulatory reform. He has published widely on international and domestic monetary and fiscal policy issues, the macroeconomics of supply, especially oil and energy price shocks, exchange rates, and on financial innovations.

Keywords: monetary policy, credit policy, central banking, Milton Friedman, business cycles.

JEL classification: E3, E5.

The views expressed are those of the individual author and do not necessarily reflect official positions of Networks Financial Institute. Please address questions regarding content to John Tatom at jtatom@earthlink.net. Any errors or omissions are the responsibility of the author.

NFI working papers and other publications are available on NFI's website (www.networksfinancialinstitute.org). Click "Research" and then "Publications/Papers." 


\section{U.S. Monetary Policy in Disarray John A. Tatom}

Monetary policy has become more difficult to characterize or follow since 2007. Before that time, matters were simpler, but still not simple. Earlier, there was a persistent debate about whether monetary policy was best characterized and understood as interest rate policy or by Federal Reserve (Fed) monetary actions to affect the growth rate of monetary aggregates. Since 2007, however, the Fed has been implementing policy actions aimed at the availability of Fed credit, especially private sector credit, as the key factor affecting the stability of financial markets, output, employment and prices. Monetary policy became credit policy in 2007 and has remained so since then. The tight link between Fed actions that change the money stock and those that affect the Fed's contribution to the stock of credit has been seriously degraded. At least for some time, there is no longer any simple measure produced by the Fed that can be taken as a benchmark for the Fed's actions to affect the economic expansion, the value of money (inflation), or financial stability.

The Fed has attempted to frame its response to the recession and financial crisis as largely following the analytical framework of Milton Friedman. For example, Nelson (2011, p. 2) cites Bernanke (2004, p. 2), who observes, “Friedman's monetary framework has been so influential that, in its broad outlines at least, it has nearly become identical with modern monetary theory and practice." Nelson argues that "An underappreciated aspect of the policy response is its consistency on many dimensions with the framework for financial and monetary policy suggested by Milton Friedman's body of work." The argument and evidence in 
this article are strongly at odds with the Fed's view of its policy and Nelson's explanation of its consistency with the work of Milton Friedman. Nelson (2011) is characterized as a Fed view here, but this is not to argue that it was promoted or supported by research colleagues or Fed officials. ${ }^{1}$

Section I discusses conventional interest rate policy and monetary base control as methods to influence aggregate demand. The Fed largely abandoned conventional interest rate policy in 2007 when it began to move the target federal funds rate to a rate below 25 basis points, or near zero. The Fed also prompted confusion over monetary actions by creating large excess reserves that blurred the Fed's actions to influence monetary aggregates. Section II details the Fed's shift to credit policy, its shortcomings, and the breakdown in the link between Fed credit and the monetary base. Credit policy shifts the focus of Fed actions away from monetary policy and, instead, stresses a critical channel for direct placement of credit to distressed non-depository private financial firms and Government Sponsored Entities (GSEs) as the principal means for countering financial crises and recessions. ${ }^{2}$ This section also provides an analysis of the payment of interest on reserves and the cost of subsidized excess reserve holding. Section III reviews recent claims by the Fed that their actions

\footnotetext{
${ }^{1}$ Nelson is the Chief of the Monetary Studies Section, Division of Monetary Affairs, Board of Governors of the Federal Reserve System since 2009; he was a research official at the Federal Reserve Bank of St. Louis from 2003-09, and was an economist and research advisor at the Bank of England from 1998-2003. Fed Research staff and officials exercise considerable independence in the subjects that they choose their analysis and conclusions at all three institutions. In particular, Nelson (2011) carries the explicit caveat: "The analysis and conclusions set forth are those of the author and do not represent the concurrence of other members of the research staff of the Board of Governors, or the Board of Governors."

${ }^{2}$ The course of action is all the more striking in light of Chairman Bernanke's speech (2002) in honor of Milton Friedman's ninetieth birthday, when he concluded “I would like to say to Milton and Anna (Schwartz): Regarding the Great Depression. You're right. We did it. We're very sorry. But thanks to you, we won't do it again."
} 
can be viewed as consistent with Milton Friedman's framework for monetary policy. Section IV provides a summary and conclusions.

\section{Conventional Fed Policy to Affect Money and Credit}

One of the great monetary policy debates for 50 years or more has been whether monetary policy works by affecting the quantity of money that circulates in the economy or by interest rate policy, which for almost as many decades has been indicated by settings of the federal funds rate. At one level, this debate was not essential since setting a nominal interest rate or setting the monetary base could be analytically equivalent if implemented in an equivalent manner, but in practice this proved unachievable. Perhaps the greatest shortcoming of interest rate policy, at least as it has been carried out by the Fed, is that it does not focus on a real rate, the type of rate that might actually influence spending, output and employment and inflation. The broader, more fundamental issue is whether monetary policy might better be exercised by control of a monetary aggregate, such as the Fed's monetary base. Monetary targeting has not received much attention since 1982, when the Fed essentially abandoned targeting the monetary aggregate, $M 1$, and later stopped paying lip service to the broader monetary aggregate M2. Instead, the Fed has ignored Congressional pressures for explicit monetary aggregate targets adopted in House concurrent Resolution 133 passed in 1975.

The old federal funds rate -- monetary aggregates debate about the efficacy and instruments of monetary policy was quieted by the fundamental and prescient challenge of Bernanke and Blinder (1988) and (1992) who rejected the usefulness of monetary measures as an indicator or instrument of policy and 
focused instead on the federal funds rate or credit spreads as part of a credit approach for a central bank to influence economic performance. Taylor (1993) provides the case for the eponymous rule explaining how the Fed could improve upon its ability to influence inflation, real GDP and the unemployment rate without reference to monetary aggregates. Once the federal funds rate was set at zero, however, the Fed resorted to direct credit measures to influence credit spreads and economic performance. ${ }^{3}$ While conventional policy became seemingly irrelevant to the Fed's leadership in 2007, at least until 2013 , it is useful to see how indicators of policy have evolved without direct policy reliance on them.

\subsection{The federal funds rate as an indicator of recent policy}

Federal funds rate changes and its level since 2008 indicate that the Fed has been extremely easy, or stimulative, because it was sharply reduced to, and has remained, near zero. The interest rates that matter for spending are real interest rates, the nominal interest rate less the expected rate of inflation. Using the personal consumption expenditure deflator over the past year to measure inflation expectations, the real federal funds rate in Figure 1 shows that the key rate sometimes moves in the opposite direction from the federal funds rate setting because of movements in expected inflation.

\section{Figure 1}

\section{The Real Federal Funds Rate Sometimes Shows Different Signals}

\footnotetext{
${ }^{3}$ Belongia and Ireland (2012) point out that Bernanke and Blinder (1982 lead the charge in arguing against the use of a monetary aggregate in the conduct of monetary policy and that Friedman and Kuttner (1992) reinforce the instability of the money -- GDP link after 1980, though Leeper and Roush (2003) reach the opposite result. Belongia and Ireland provide a new theoretical basis, backed by empirical support, for including a monetary aggregate in the implementation and assessment of monetary policy.
} 


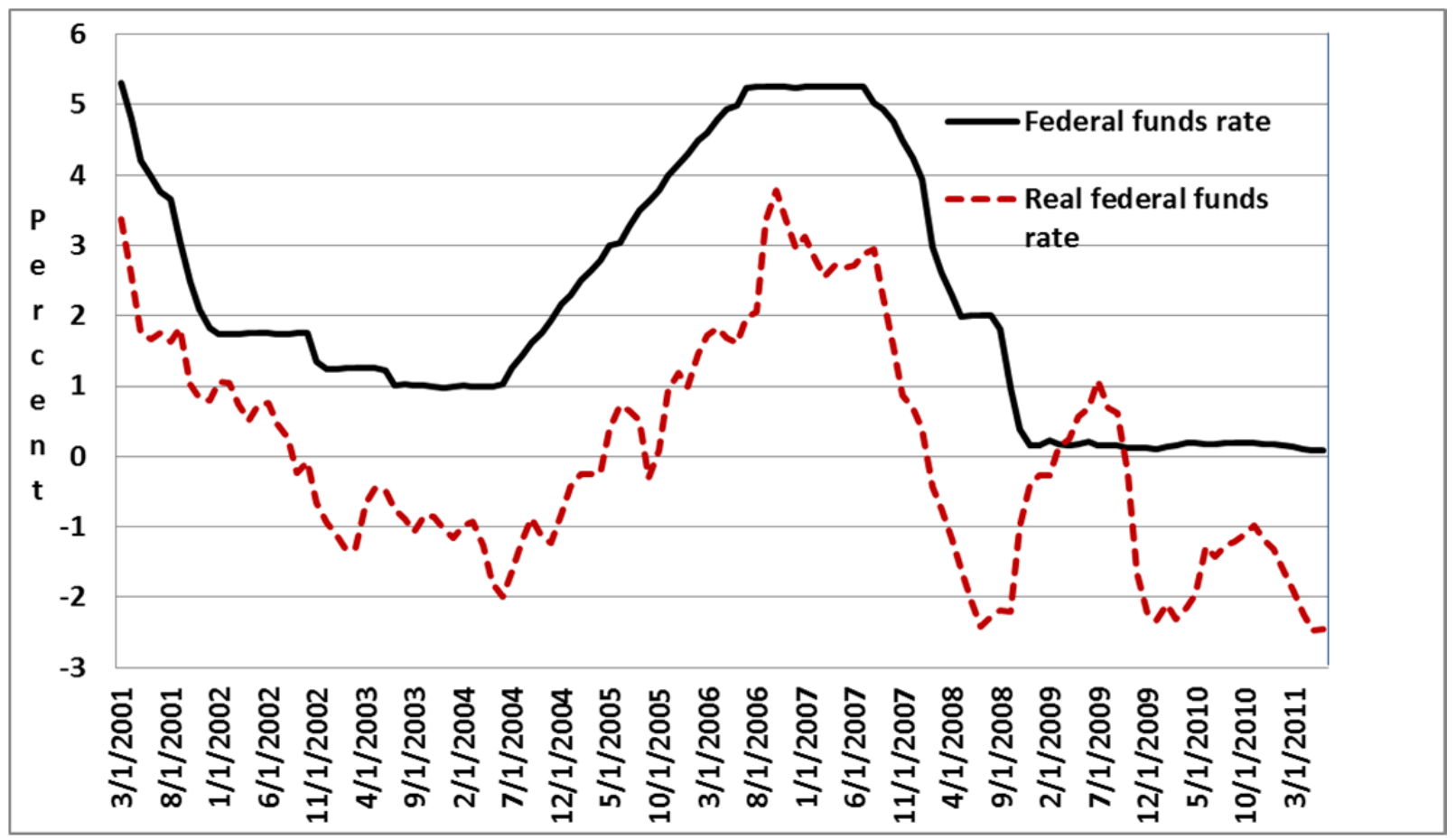

Source: Federal Reserve Bank of St. Louis, FRED database

In particular, from July 2008 to July 2009 and again from December 2009 to November 2010, the real federal funds rate rose, and quite sharply. ${ }^{4}$ In the first instance, the Fed allowed its policy to become tighter, inadvertently deepening the recession and contributing to the financial crisis two months later and subsequently delaying and in the second instance weakening the recovery. The

\footnotetext{
${ }^{4}$ If the real interest rate is constructed using the ex ante University of Michigan inflation expectations measures the surge in the real rate in these two periods is not as large. Recent swings in inflation associated with surges in energy prices and subsequent declines may not affect the University of Michigan expected inflation measure. However, both expected inflation measures are not immune to energy price swings before then and the PCE deflator is usually a better predictor of future inflation. The 10-year constant maturity TIPs yield shows four spikes in the real interest rate since the recession began: March 2008 to November 2008 (180 basis points), April 2009 to June 2009 (31 basis points), November 2009 to March 2010 (23 basis points), and October 2010 to February 2011 (71 basis points). The first period is the run-up to and worst part of the financial crisis during the recession, the second period is at the end of the recession and the third period matches the first four months of the surge shown in Figure 1.
} 
former increase is reminiscent of the sharp increase in the Fed's nominal and real discount rate in midst of the Great Depression in October 1931 that was kept in place until June $1933 .^{5}$

\subsection{The monetary base and the recent recession and recovery}

Many analysts have long emphasized that the Fed should target the annual growth rate of a monetary aggregate in order to achieve macroeconomic objectives. For example, see Andersen and Karnosky (1977). Monetary aggregates measures, such as the narrow measure $\mathrm{M} 1$, have come into question for a variety of reasons, including the fact that much of a key component, currency, is held abroad and is therefore unlikely to affect domestic economic activity or prices. Sweep practices of depository institutions have also affected M1, but estimates of sweep balances can be incorporated.

Changes in one measure, the monetary base, reflect Federal Reserve actions that influence monetary aggregates. Meltzer (1987) and McCallum $(1988,2000)$ develop policy rules for the use of the monetary base to control GDP and inflation. The monetary base equals the assets of the Fed, netting out some uses of the monetary base that restrict the availability to support its two main uses: currency holdings of the public and reserve holdings of depository institutions. Increases in the growth rate of the monetary base are expected, with a lag, to boost the growth rate of broader monetary aggregates and, in turn to increase spending growth, and temporarily the growth rate of output and employment.

\footnotetext{
${ }^{5}$ This is not to argue that the Fed's recent actions paralleled those during the Depression. In the early 1930s, the Fed allowed the money stock to decline some 25 percent causing rapid declines in spending, output and prices.
} 
Eventually, however, a more rapid increase in the monetary base and spending are expected to result only in a higher inflation rate.

In a simple model of the money supply process the monetary base is tightly tied to broader monetary aggregates via a multiplier. ${ }^{6}$ The narrow monetary aggregate M1 multiplier depends upon the currency ratio (c), the ratio of currency in the hands of the non-bank public (C) to transactions deposits (D), the ratio $(p)$ of required reserves (RR) to transactions deposits, and excess reserves (ER) as a desired ratio (e) to transactions deposits. Broader monetary aggregates take into account the additional components that are not part of $\mathrm{M} 1$, each expressed as a desired ratio to transactions deposits. ${ }^{7}$ The excess reserve ratio is a trivial component of the multiplier until fall 2008, but afterwards it explodes. ${ }^{8}$ To correct for this a simpler model of the money supply process is used that omits excess reserves from the monetary base and multiplier. This measure, called the "monetary base adjusted" here, subtracts excess reserves from the monetary base. ${ }^{9}$ In a the not seasonally adjusted monthly data used here the

\footnotetext{
${ }^{6}$ See Rasche and Johannes (1987) for an exposition of how one can model components of the multiplier in order to control monetary aggregates or Hafer and Hein (1984) for a time series approach to the multiplier itself. Also see Anderson and Rasche (1996) and references there for the literature on measuring the monetary base.

${ }^{7}$ The multipliers are only stable if one adjusts transactions deposits to include sweep balances (See www.sweepmeasures.com).

${ }^{8}$ Keister, Martin and McAndrews (2008) note the equivalence between a monetary aggregate approach to the conduct of monetary policy and an interest rate policy. They argue for setting a target interest rate on excess reserves to break the link between money and reserves or money and interest rates, in order to avoid tensions between monetary policy and payments or liquidity policy and to promote efficiency in resource allocation by developing an explicit return to holding reserves to offset the opportunity cost. However, there has always been a return to holding excess reserves that they ignore. Their article is a useful primer on Fed thinking on the benefits of boosting excess reserves.

${ }^{9}$ Typically the appropriate monetary base measure is adjusted for reserve requirement changes and called the adjusted monetary base (AMBNS in FRED for the not seasonally adjusted monthly measure). There have been no major changes in reserve requirements for 20 years, however.
} 
monetary base adjusted is found as the Board of Governors Monetary Base (FRED code BOGUMBNS) less excess reserves (FRED code EXCRESNS).

In the simple model of the Fed and depository institutions, the Fed balance sheet consists of reserve bank credit (RBC), which includes credit to depository institutions (L), other private credit (PC) and Treasury securities (TS) and its liabilities include C, RR, ER and other deposits and liabilities (O). The monetary base $(M B)$ is the sum of currency, required reserves and excess reserves and its sources are RBC less $\mathrm{O}$. Depository institutions balance sheet assets are credit (CR), which could be securities or loans, RR and ER, and its liability is transactions deposits. In this model,

$$
M=[(1+c) /(c+p+e)] M B
$$

Since excess reserves absorb some of the monetary base but do not contribute directly to $M$, they can be deducted from the monetary base measure to obtain the monetary base adjusted, MBA, and equation (1) may be rewritten as (2).

$$
M=[(1+c) /(c+p)] M B A
$$

This expression is more useful heuristically when excess reserves are very small, as was the case before 2008 , or where excess reserves are subject to large shocks due to the introduction of payment of interest, especially at a subsidized

The difference in the mean of the Board of Governors monetary base used here (FRED code BOGUMBNS) and the Federal Reserve Bank of St. Louis adjusted monetary base monthly (FRED code AMBNS) from 2000 to June 2011 is only 4 basis points and the same is true of the standard deviation of the two series for the same period. So there is essentially no difference in the two measures over this period. The same approach could be taken for the excess reserve ratio in the multiplier at a base period level as is taken for the required reserve ratio and allowing variations in it around this level to affect the reserve adjustment magnitude, with reduction (additions) in the ratio adding to it (subtracting from it). For the purposes here, this refinement is unnecessary. 
rate. It is also more useful if one is interested in a stable multiplier, the bracketed term in equations (1) or (2).

Figure 2 shows the growth rate of the monetary base adjusted and nominal GDP, the growth rate of spending. The growth rate of the monetary base slowed until the third quarter of 2000 , leading to the recession in II/2000 to IV/2001, reflected in the slowing of GDP growth. Subsequently, faster monetary base growth led to an acceleration of GDP growth.

\section{Figure 2}

Monetary Base Growth Leads the Growth Rate of GDP

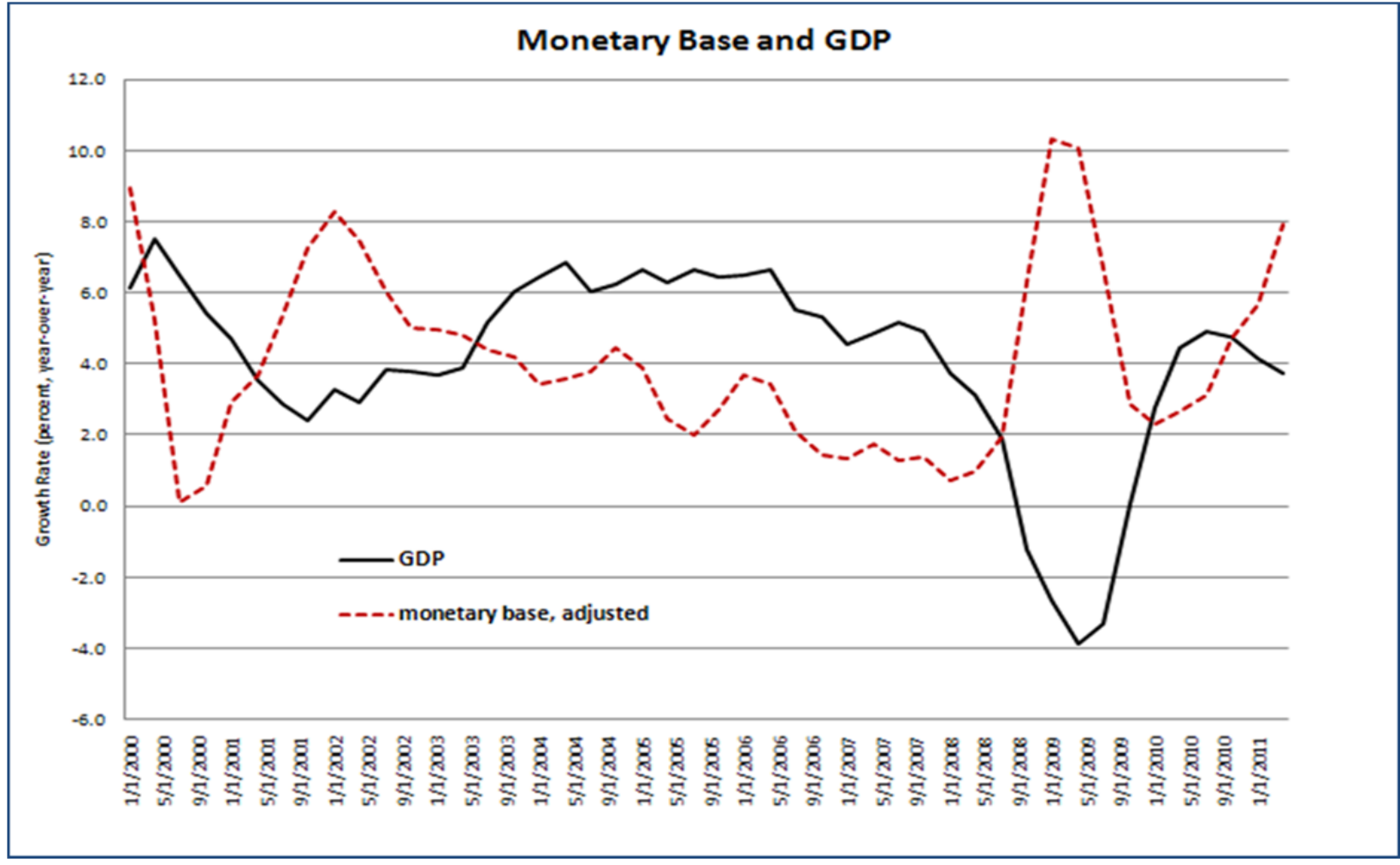

Source: Federal Reserve Bank of St. Louis, FRED database

Monetary base growth was then sluggish for several years, declining to a relatively torpid pace of 0.7 percent in the first quarter of 2008. GDP growth 
reflected that slowing, with a lag, and was lethargic enough to enter recession in IV/2007. Tatom (2006) warns of the recessionary pace of monetary base growth about a year before the onset of the recession and Hetzel (2009) has drawn the same conclusion. Monetary base growth rose slightly in the next two quarters. Even then, most of the new private credit extended by the Fed was sterilized initially so that monetary base growth did not exceed even the recessionary pace of 1.9 percent growth by the third quarter of 2008 . This acceleration strengthened following the onset of the financial crisis and led to an acceleration in GDP growth that brought the recession to an end in II/2009. Note, however, that monetary base growth then slowed from January 2009 to January 2010, despite the near-zero and unchanged federal funds rate. Thus, again with a lag, the growth rate of spending began to slow from the third quarter of 2010 until early 2011. The monetary base accelerated from a 2.3 percent pace in January 2010 to a 7.9 percent rate in April 2011, which can be expected to lead to an increase in spending growth.

The monetary base adjusted continues to provide a useful indicator of monetary policy, at least in terms of Federal Reserve actions that will influence spending or GDP. It differs from the signals provided by the real federal funds rate, but the monetary base adjusted measure shows tightening before the recession and both measures show tightening during some periods during and after the recession. ${ }^{10}$ Certainly there were other shocks that could account for the

\footnotetext{
${ }^{10}$ Taylor (2009) argues that there was not a liquidity problem heading in to the financial crisis, but rather a counterparty risk problem. The evidence here indicates that there was in fact a liquidity problem as evidenced by the weak growth of MBA. It began well before the onset of recession and continued up to the onset of the financial crisis. Such a liquidity shortage, together with failures of large investment banks, should be expected to lead to a counterparty risk problem.
} 
extended recession and long and weak recovery, such as energy price shocks, sovereign debt developments in Europe, or ongoing house price declines, but monetary actions summarized in the monetary base adjusted go a long way to provide an explanation alone.

\section{The Introduction of Credit Policy}

In 2007 the Fed accelerated its shift to a credit policy, expanding lending to the private sector. Many analysts have referred to this as the Fed taking on a fiscal policy role by lending to investment banks and other financial institutions that had not had access to the Federal Reserve for 70 years, except as primary dealers in Treasury securities. It can also be characterized as credit policy because the Fed conducted policy actions to achieve credit expansions to targeted parts of the financial markets, largely to non-depository institutions. ${ }^{11}$

Nelson (2011, p.28) indicates why the Fed departed from traditional monetary policy, despite his effort to otherwise find consistency with Milton Friedman's framework: "It was precisely this aspect of the Friedman-Schwartz account of the Great Depression which Bernanke $(1983,2002)$ used as motivation for an alternative view that the credit contraction mattered in its own right. From the latter perspective, there is an important role for intervention in credit markets to

\footnotetext{
${ }^{11}$ Goodfriend (2011) also recognizes the shift to credit policy and separates an interest on reserves policy as another lever for monetary or credit policy, as explained below. The definition of credit policy is not universally agreed. Gertler, Kiyotaki and Queralto (2011) characterize central banking as including "an advantage over other financial institutions because they can easily obtain funds by issuing short term government debt." Presumably this refers to monetary policy, not credit policy. This is also an example of confusing the difference between central banks that can create money and other financial institutions that have to fund asset acquisition by increasing liabilities or reducing existing assets.
} 
preserve intermediation, as opposed to the interventions designed to maintain the money stock that Friedman emphasized."

Another key change in conventional policy in 2007 was that the Fed abandoned a policy on lending to depository institutions that it had adopted in 2003 (see Wheelock 2003). Earlier (1986 through 2002) depository borrowing averaged about $\$ 540$ million weekly. When the Fed adopted a penalty rate of one percentage point over the federal funds rate in 2003, primary and secondary credit to depository institutions fell to an average of $\$ 49$ million and remained very low until 2007. The Fed broke the fixed link between the primary credit rate and federal funds rate in mid-2007, beginning a series of changes in the primary credit rate and swings in its spread over the federal funds rate that led to large swings in borrowing. In February 2010 the Fed raised the primary credit rate to 75 basis points, where it has remained since then and borrowing again has been relatively low.

Borrowing had been limited because of the policy of a penalty credit rate, but varying the penalty led to large swings in borrowing. One might argue that these large swings were due to events associated with the financial crisis, but they were largely unrelated to any crisis event. The Fed could soon move to the higher and fixed penalty spread that it had in place from 2003 to August 2007 since depository borrowing has returned to a very tiny level, but this may be less likely if the Fed wishes to continue its ability to exercise a discretionary credit policy independent of monetary policy.

The abandonment of the new discount policy was a major break in monetary policy. Once again, discretion triumphed despite the theoretical arguments 
favoring a rule. Many analysts, including Friedman (1959), had argued that discount policy was inefficient, distorted and confused monetary policy and simply redistributed income to banks through subsidized loans. More importantly, Friedman argued that the problem of distinguishing insolvent banks from illiquid banks was best solved by using traditional open market operations and allowing the banking system and credit markets to channel new credit to illiquid, but not insolvent, institutions. See Schwartz (1992) for a discussion of the problems with discount policy, which were largely alleviated in 2003 and then partially resurrected in 2007.

The biggest changes in Fed policy were the introduction of numerous programs to lend to primary dealers, both banks and other financial institutions that were allowed to borrow, purchase, sell or lend U.S. government securities with the Fed, as well as new facilities to buy asset backed commercial paper from money market funds and to lend to these institutions and others against such assets (see the Federal Reserve Bank of St. Louis timeline, http://timeline.stlouisfed.org). The particular assets weekly can be found in the Board of Governors' H4.1 Release. These funds are largely Mortgage-Backed Securities, agency debt, Asset-Backed Securities Loan Facilities and various Maiden Lane programs. There were also some other facilities for TALF, AIA LLC, Aurora LLC and ALICO Holdings LLC. The Fed also provided funds to acquire and manage a portfolio of Bear Stearns toxic assets when it was purchased by JP Morgan Chase in May 2008. Eventually, the Fed even lent about \$85 billion to AIG to provide it liquidity as it failed in fall 2008. Such private sector lending is highly unusual for a central bank and exposes the Fed and the taxpayer to substantial financial risk, not to mention the loss of its credibility and reputation 
in financial markets. ${ }^{12}$ See Klueh and Stella (2008) and Ize and Oulidi (2009) for the experience in poorer and emerging economies. The latter paper emphasizes that weak banks can have unusually high profitability, as the Fed has had since 2007, due usually to fiscal dominance. Ford and Todd (2010) attribute the surge in Fed profits since 2006 to unusually risky assets. ${ }^{13}$

\section{II.1 The limitations of credit policy}

The difficulties of weak growth of the monetary base leading up to and during the recession, as well as during critical periods of the recovery, arose because of a focus on credit policy, especially a focus on the Fed's provision of private sector credit. In the money supply process model above, the total credit supplied by the Fed directly through RBC and through the banking systems' supply of CR can be found by consolidating the balance sheets to find TC. ${ }^{14}$

$$
\mathrm{TC}=\mathrm{M}+\mathrm{O}
$$

\footnotetext{
${ }^{12}$ Tatom (2009) reviews the risks, market distortions, inefficiencies and opacity of the new Fed programs up to mid-2008 and their effects on the Fed's credibility and transparency compared with traditional open market operations that allow markets to funnel credit to the illiquid financial and non-financial institutions. Taylor (2010) also points to the failure of these new Fed policies to stimulate the economy. For an alternative view see Aglietta and Scialom (2009) and Chadha, Corrado and Meaning (2012). The latter emphasize that nonconventional monetary policies affect liquidity, though in principle this is incorrect. Balance sheet policies transfer liquidity from the central bank to the private financial sector, but they do not affect overall liquidity.

${ }^{13}$ Mortgage- backed securities issued by Fannie Mae and Freddie Mac are treated here as private even though these two institutions were put under the conservatorship of the U.S. Treasury in September 2008, just prior to the financial crisis. Several months later, the Fed began a program to acquire a large amount of these securities as part of the first quantitative easing program. These securities are longer term and carry substantial interest rate risk, even if their credit risk was removed by government conservatorship.

${ }^{14}$ Equation 3 does not depend on any of the model behavioral assumptions. It can be derived from the consolidated balance sheets of the model.
} 
The Fed can only influence the total credit in the economy through the money supply process by altering the money stock or by changing its "other deposits and liabilities." Banking system intermediation of credit through time deposits or other non-transactions deposits can influence banks' share of the credit that arises from public saving, but, given $M$, it cannot change the flow of credit created through the money supply process. ${ }^{15}$ The Fed's efforts to change its credit, especially credit provided to non-depository private firms, can only influence total credit if it changes $\mathrm{M}$ or $\mathrm{O}$. Otherwise, an increase in RBC, whether private sector credit or Treasury securities, given $M$, must result in an offsetting change in credit supplied by depository institutions in order to accommodate the equivalent rise in excess reserves.

Increases in the Fed's "other" liability--say by boosting Treasury deposits at the Fed--can increase RBC and TC. Suppose Treasury deposits at the Fed are boosted by the Treasury issuing new securities, the proceeds from which are held at the Fed. In order to keep MBA unaffected as the public provides the funds to the Treasury, the Fed would have to offset the drain of required reserves by expanding RBC. Total credit supplied to the private sector would not change, however. RBC and $\mathrm{O}$ would rise by equal amounts and equal to the rise in Treasury deposits, but credit available to the private sector would be unchanged. Another source of other liabilities is deposits by foreign central banks. These are less able to be manipulated by the Fed, but an increase in such deposits can boost RBC and TC at the expense of the foreign country's RBC.

\footnotetext{
${ }^{15}$ Banks also raise equity and have done so in recent years, largely to replace lost equity due to asset losses. Adding equity to the balance sheet of depository institutions would add an equity term to equation 3 , but would not affect the generality of the results or conclusions here.
} 
Fed efforts to increase RBC, in particular its private component, PC, by reducing TS or boosting its excess reserves, cannot change the total credit in the economy, given MBA and $\mathrm{M}$. This is one of the fundamental flaws of the Fed attempting to increase the private component of RBC by reducing TS, or by increasing ER so as to keep MBA and M unaffected. Increases in government deposits at the Fed can increase RBC and TC, but by amounts that exactly match the new creation of Treasury debt, so the increases in deposits would not affect the overall credit available to the private sector. Fed reliance on expanding private sector credit without affecting $\mathrm{M}$ must rely on theoretically unexplained and empirically unsubstantiated stimulus effects that arise because the Fed's credit to the private economy has more effect on spending than an equal amount of Treasury security purchases or loans to depository institutions. ${ }^{16}$ It is also possible that the magnitude of the Fed's balance sheet change or other unusual changes in policy could have altered the effects of conventional measures of monetary policy. Again, no evidence has been presented to support such a claim.

The simple money supply process model can also be used to derive the amount of private credit provided by the Fed. In particular, PC can be expressed as:

$$
P C=[M /(1+c)](p+c+e+o)-T S
$$

\footnotetext{
${ }^{16}$ Joyce et al. (2010) provide evidence of a portfolio balance effect of 2009-10 quantitative easing on gilt yields in the United Kingdom. There is no evidence presented that the effect on yields differs from the normal effects of the associated rise in the monetary base. Giannone et al. (2012) provide evidence that non-traditional ECB policy boosted loans and real economic activity, but again their simulation includes an expansion in the monetary base and the effects are not separated.
} 
Equation 4 shows that the Fed can boost its private credit without changing $M$ (or TC), by boosting excess reserves, in particular by raising the interest rate on excess reserves, $\mathrm{i}_{E R}$ to boost e, by reducing its Treasury security holdings, TS, or by increasing 0 . These are the non-traditional actions the Fed has used to expand private sector credit. The Fed has taken these actions with the apparently mistaken view that it would affect total credit and that the Fed supply of private credit is somehow more important than credit supplied by the Fed on government securities or private bank credit extensions. Its actions are a reminder of criticisms the Fed's earlier reliance on commercial-bank-type actions during the Great Depression.

In that instance, Epstein and Ferguson (1984) argue that the Fed responded primarily to pressures from the large commercial banks and so they were reluctant to conduct open market operations that might lower interest rates and earnings during 1929-33. Fed actions noted by Friedman and Schwartz (1963) and Meltzer (2003), such as holding back on open market purchases, closing large numbers of commercial banks on the suspicion of insolvency in a liquidity crisis, or reducing open market purchases when discount lending increased (asset substitution), were typical of actions of commercial banks. The same is true for actions such as raising reserve requirements when excess reserves were relatively high amid concern of banks undertaking a credit boom sound quite similar to commercial banks cutting unused credit lines when they are concerned about the potential for declining credit worthiness. ${ }^{17}$ The lack of attention to avoid a massive decline in the money stock, not to mention to the failure to promote a sharp increase in the money stock, reinforce the view that the Fed

\footnotetext{
${ }^{17}$ A recent paper by Calomiris, Mason and Wheelock (2011) provides an alternative nonmonetary explanation of the rise in the reserve ratio during the period.
} 
had insufficient concern to increase liquidity in the face of a liquidity crisis. The Fed was not adequately aware of its ability to boost its liabilities by acquiring assets and the benefits from such actions.

\section{II.2 The breakdown of the link between the Fed credit and money}

Figure 3 shows the breakdown in Fed policy. Until December 2007, Treasury securities held outright were about 90 percent or more of Federal Reserve Credit, the major asset category on the Fed's balance sheet, and of the total assets of the Fed. Small amounts of loans to depository institutions, and, since 2008, portfolios of other assets acquired by the Fed to direct credit to the private sector make up the rest of Federal Reserve Credit. Treasury securities were also the major component of the monetary base until that time. Thus there was essentially no difference between credit policy and monetary policy as the Fed bought Treasury securities in order to provide public sector credit and to increase the monetary base and monetary aggregates.

Beginning in late 2007, however, these tight links were broken by the Fed actions to boost RBC, especially its private sector component, through commercial-banktype actions such as reducing other assets (TS) or attracting new funding, such as excess reserves or new idle Treasury deposits. Indeed, Treasury securities held outright were sold off in order to fund private depository loans and to provide facilities for non-depository institution credit and other private sector asset purchases. Treasury holdings fell from a peak of $\$ 790.7$ billion in July 2007 to $\$ 474.8$ billion in February 2009 in order to make room for expanded private sector credit on the Fed's balance sheet. 


\section{Figure 3}

\section{The Broken Link between the Fed's Monetary Base and Reserve Bank Credit}

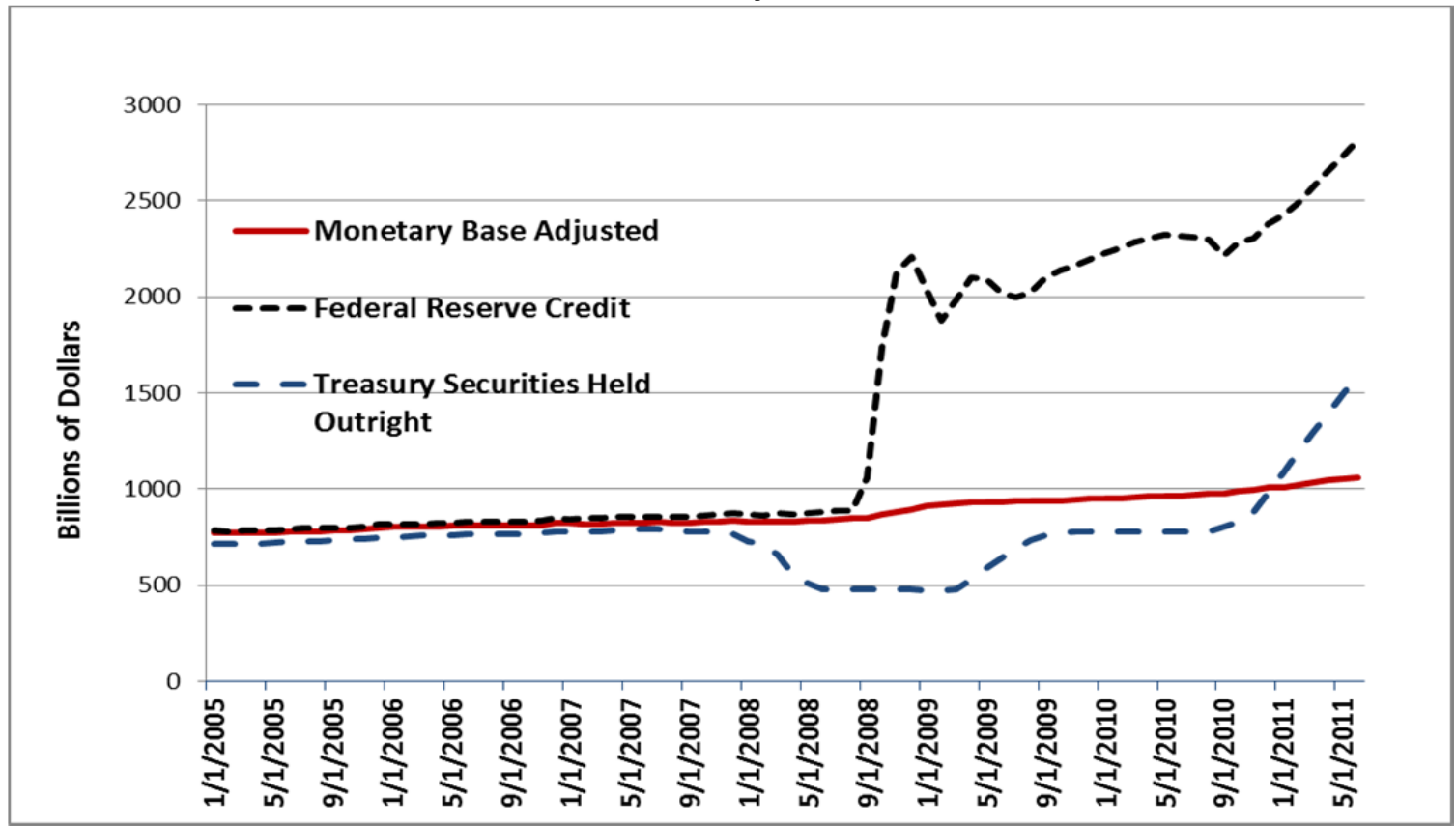

Source: Federal Reserve Bank of St. Louis, FRED database

As a share of Federal Reserve Credit, Treasuries fell to 21.6 percent in December 2008. Most of the reduction in Treasuries was accomplished before the financial crisis as the growth of the monetary base was held to a recessionary pace of 1.9 percent over the year ending in III/2008 (Figure 2). The Fed essentially sterilized the expansion of bank and private sector lending by reducing Treasury security holdings during this period.

Treasury securities held by the Fed rose slightly from March 2009 to September 2009 but were then nearly flat for a year, a period that encompasses much of the Feds' first period of quantitative easing. A more sustained and larger rise began in September 2010, but did not reach 50 percent of the Federal Reserve Credit until spring 2011. Fed holdings of Treasury securities rose above the 
monetary base adjusted in March 2011 and is an increasing share of Federal Reserve Credit. Holdings of other riskier securities remain nearly as large, however, so the Fed's credit and interest rate risk remain unusually high compared with levels prior to 2008. The Fed held one trillion dollars of agency and MBS debt as late as August 2011 (see the Fed's H.4.1 Release dated August $25,2011)$. The agency debt was so risky that the Fed had never held such assets before, except for holding only $\$ 10$ million of these assets briefly from 2002 to December 2003. ${ }^{18}$ MBS were not held at all until January 2009, despite the explicit Government guarantee that came into effect in August 2008. The Fed also continues (as of August 2011) to have an interest in some $\$ 50$ billion in various junk securities as portfolio holdings and $\$ 11.7$ billion of other questionable asset-backed securities that are secured by credit risk protection from the U.S. Treasury. Credit losses on these Fed assets are only redistributed within the government; taxpayer losses from these assets are not avoided.

The holdings of Treasury securities have also become riskier because the portfolio is longer term, exposing the Fed to substantial interest rate risk when Treasury security rates begin to rise. In early August 2011, almost 50 percent of the Fed's holdings of Treasury securities had maturities beyond 10 years and over 90 percent matured in five years or more, an extremely long duration for a central bank or any bank. Ford and Todd (2010) have pointed out that the sharp increase in risk, interest rate and credit risk, since 2006 has boosted Fed profits. Even a modest rise in market interest rates would eliminate the equivalent of

\footnotetext{
${ }^{18}$ Fannie Mae and Freddie Mac were taken into conservatorship by the U.S. Treasury on September 6, 2008. The average 10 year spread of Fannie Mae debt over the comparable Treasury security was 46.3 basis points for the three years ending September 6, 2008 and 32.3 basis points for the subsequent three years, according to Barclay's data. So the spread remained and was not much smaller after the explicit guarantee was created than it was before.
} 
many years of Fed earnings according to Carpenter, Ihrig, Klee, Quinn and Boote (2013). Of course the Fed could hold the securities to maturity and avoid a loss of principal, but that constrains the ability to reduce Fed assets when and if it should wish to reduce excess reserves to a more normal level. The Fed is holding nearly one trillion dollars of medium and relatively long term private sector loans, mortgage-backed-securities, agency securities and private sector assets. They cannot readily be sold without losses.

A second source of the breakdown in the link between the effective monetary base and RBC was the Treasury Supplementary Financing Program. It began on September 17, 2008, within days of ground zero for the financial crisis, or at least when Lehman Brothers failed, Merrill Lynch and Wachovia Corporation had to be taken over, Reserve Primary Money Market Fund "broke the buck" and the Fed loaned some $\$ 85$ billion to AIG. The Treasury announced the new program to sell marketable securities, the proceeds from which they promised to leave on deposit at the Fed. Officially, the Fed and Treasury indicated that the purpose of the deposits at the Fed was to drain reserves that had been created by new credit facilities. In the notes that the Fed issues with its H.4.1 Release, the Fed states:

"The effect of the accounts is to drain balances from the deposits of depository institutions, helping to offset, somewhat, the rapid rise in balances that resulted from the various Federal Reserve liquidity facilities." 19

\footnotetext{
${ }^{19}$ See the H.4.1 Release, Factors Affecting Reserve Balances, any issue after September. The notes can be found for the table at http://www.federalreserve.gov/monetarypolicy/bst frliabilities.htm under the "Deposits of the
} 
This is technically sound, but if this outcome was truly what the Fed and Treasury intended, there should be evidence that reserves fell by a like amount. Consider a thought experiment. Suppose the Fed simply acquires private assets at the same time that it receives the funds from the Treasury for the sale of securities. The Fed gains private assets on the left hand side of its balance sheet, and it increases its non-monetary base liabilities (the Treasury balance at the Fed) on the right hand side of the balance sheet. With this thought experiment, the Fed acts like a commercial bank instead of a central bank. It acquires a liability to fund an asset acquisition.

Which view is correct, the Fed's explanation or the thought experiment here? The Fed's explanation suggests that there should be a significant negative correlation between the increase or decreases in the Treasury's supplementary financing account balance and changes in total reserves at the Fed. In addition, there should be no correlation between changes in the supplementary financing balance and the change in private assets at the Fed. In fact, for the 132 weeks from September 24, 2008 to March 30, 2011, after which the supplementary balance was frozen at only $\$ 5$ billion, the correlation between weekly changes in the Treasury Supplementary balance and the change in total reserves was negative, -0.027 , but not statistically significantly different from zero. Over the same period, changes in the supplementary balance and Reserve Bank Credit have a correlation coefficient that is positive, 0.547 , and statistically significantly different from zero at a 1 percent significance level $(t=7.44)$. These results strongly reject the Fed explanation and support the commercial bank view.

U.S. Treasury" section. I am indebted to Kevin Kliesen and Yvette Fortova for help in finding the original source for the notes description. 
The Fed has used the Treasury's supplemental financing balances to finance an expansion of private asset holdings, just as a commercial bank would do with their own liabilities. When private assets are measured by subtracting the Fed's Treasury securities held outright from its Reserve Bank Credit, the correlation between changes in private assets and the change in the supplementary reserve balance is 0.560 , again positive and highly statistically significant $(t=7.70)$. Thus, one must conclude that the Fed's arrangement with the Treasury to sell securities and idly hold the funds in a deposit balance at the Fed was a prime example of the Fed engaging in commercial banking-like activity reminiscent of the Depression. Very simply, the Fed could have increased its private sector assets by making the loans and increasing the monetary base, just as it would if it engaged in open market operation. But apparently the Fed did not want to expand the monetary base, only its credit supply, and this credit policy was facilitated by the cooperation of the Treasury. A third source of the breakdown in the link between the effective monetary base and RBC is the surge in excess reserves since 2007 .

\section{II.3 Paying interest on excess reserves}

As in 1937-38, the demand for excess reserves recently has also been large, perhaps due to memories of the liquidity problems in 2007-08, but perhaps because of an attractive subsidy to holding excess reserves that began in October 2008. Keister, Martin and McAndrews (2008) refer to this development as "Divorcing Money from Monetary Policy" by setting a target rate for interest on reserves to encourage excess reserve holding. Bech and Klee (2011) take an alternative tack, arguing that the interest rate on reserves is intended to put a floor on the federal funds rate, but, they explain, it has failed to do so because of 
the absence of interest on deposits of Government Sponsored Enterprises. So long as a subsidy on reserves is sufficiently large, it may induce banks to bid for federal funds from GSEs so that they can earn a subsidy on excess reserves. In fact, the federal funds rate carries a counterparty risk premium that is absent from the interest rate on excess reserves. ${ }^{20} \mathrm{~A}$ simpler explanation of a relatively lower federal funds rate is that both are set or targeted this way by the Fed.

Milton Friedman (1959) recommended the payment of interest on reserves, which did not begin until 2008. But he recommended that the interest rate paid should be comparable to a safe rate on short-term funds, closer to the Treasury bill rate, not the 25 basis points that the Fed has paid since December 2008, much higher than the federal funds rate or Treasury bill rate. ${ }^{21}$ The motivation is that required reserves act as a tax on banks and reduce the efficiency of the banking system with little or no benefit to the Fed, banks or their depositors. Friedman does not distinguish excess and required reserves, though his argument applies to required reserves only. Banks voluntarily hold excess reserves in return for their in kind benefits, at least until interest payments on excess reserves began in 2008.

Kashyap and Stein (2012), following Goodfriend (2002), Martin and McAndrews (2008), Bech and Klee (2011) and others, confuse the federal funds rate with

\footnotetext{
${ }^{20}$ Bowman, Gagnon and Leahy (2010) examine eight countries that pay interest on excess reserves to examine whether raising the rate on excess reserves tightens monetary policy by raising short term interest rates and whether the rate serves as a floor on other policy rates. Except for the U.K and U.S. the rate is a floor and raising it is a way to tighten policy. When the rate was raised in late 2008 , the monetary base adjusted was beginning to accelerate (Figure 2 ).

${ }^{21} \mathrm{Ed}$ Kane has pointed out privately that the interest rate on excess reserves should be set lower than the federal funds rate because excess reserves also carry an option of unlimited duration that federal funds do not. Presumably the same is true for the safe rate on Treasury bills which also do not carry this option.
} 
Friedman's recommended safe rate as the appropriate guide to efficiency. They also follow Bech and Klee (2011) and others in viewing an interest rate on reserves as providing a floor to the federal funds rate in a corridor system, despite the fact a federal funds loan carries credit risk and reserves have a free duration option that federal funds loans do not. In the short history of paying interest on reserves, the federal funds rate has been lower than the interest rate on reserves, implying, in their framework, a negative "scarcity value of reserves," despite the existence of a subsidy on holding reserves. The average value of the effective federal funds rate has been almost 10 basis points lower than the interest rate on reserves in every month from October 2008 to June $2011 .^{22}$

Kashyap and Stein (2012) adopt a normative notion of optimal policy under which the Fed focuses on two goals, targeting GDP and financial stability. In their view, a target interest rate on reserves would aim for financial stability and would likely differ from the federal funds rate target. Kashyap and Stein ignore the fact that using this interest rate to affect excess reserves and commercial bank credit would not affect total credit and would simply move credit from the banking system to the Fed or the reverse, as explained above (section II.1).

Had Friedman's recommendation been followed, excess reserves would be much lower today. The payment of excessive interest on reserves began half way through the recession and was tied to the Fed's effort to build up its private sector credit without boosting the monetary base adjusted. New excess reserves simply reflect new asset acquisitions by the Fed (sources of the monetary base).

\footnotetext{
${ }^{22}$ Bowman, Gagnon and Leahy (2010) also follow the same flawed approach that ignores the credit risk of federal funds transactions, the non-pecuniary benefits of excess reserves and the duration option offered by excess reserves, and that views the interest rate on excess reserves as an attractive new monetary policy tool.
} 
This subsidy is part of the Fed's return to a Depression-era practice of acting as a commercial bank instead of as a central bank, in this case by increasing its liabilities that are not associated with the money stock in order to boost its credit assets.

\section{II.4 The cost of excess reserves}

The Fed has made little attempt to reduce its assets since the end of the financial crisis (see Figure 3) despite the fact that the recession ended in June 2009 and the financial crisis even longer ago. And the Fed is more illiquid and riskier than it was then or before the recession. It is no wonder, therefore, that the Fed is paying a large subsidy to keep its excess reserves, which is roughly equal to the difference between Federal Reserve Credit and the monetary base adjusted in Figure 3. Proponents of payment of interest on reserves have typically suggested that the rationale was to compensate banks for the opportunity cost of holding short term funds at the Fed with the rate they could earn on similar holdings of Treasury bills. But the 25 basis points the Fed pays on excess and required reserves far exceed that level. The cumulative sum of excess payments to banks, based on the difference in the interest rate on reserves and the 30-day Treasury bill rate from January 2009 to June 2011, equals $\$ 3.3$ billion, or $\$ 1.3$ billion per year, a substantial taxpayer subsidy to banks and other depository institutions just to keep the Fed from having to take losses on its massive holding of illiquid assets. ${ }^{23}$ But the interest payments on excess reserves are all a theoretically unsupported payment and the subsidy of the T-bill rate over zero adds \$3.1

\footnotetext{
${ }^{23}$ The Fed's concerns for the effects of lowering the interest on reserves on money markets and the fed funds market have been cited as reasons for not doing so. For example, see the minutes from the September 20-21, 2011 Federal Open Market Committee meeting. These concerns have not been spelled out in any detail.
} 
billion for the 30 months or $\$ 1.3$ billion at an annual rate. Together, the total subsidy or misapplied interest on reserves is $\$ 6.5$ billion for the 30 month period, or \$2.6 billion per year. Going forward, based on the subsidy and reserve levels of the first half of 2011, the subsidy over the T-bill rate on all reserves would be $\$ 2.3$ billion per year, and adding in the payment of the T-bill rate for excess reserves, the total subsidy is $\$ 3.6$ billion per year, and this amount will grow if excess reserves grow. The total subsidy equals 3.5 percent of the net income of all FDIC-insured banks for the same period, though it is a tidy zero-risk sum. Nearly all the subsidy arises from excess reserves, which averaged 97.5 percent of total reserves during the whole period. ${ }^{24}$

Of course there are other large private sector subsidies because of the new credit and reserve policies of the Fed that were not necessary in order to pursue the monetary and Federal Reserve outcomes. See the General Accounting Office (2011) for other inefficient and unnecessary private sector payments.

The Fed could have increased the monetary base adjusted simply by adding to their holding of Treasury securities and not inflating the interest rate paid on excess reserves. Over the 42 months from December 2007 (the business cycle peak) to June 2011, the Fed could have increased the monetary base by 7 percent per year to smooth out the swings in monetary base growth and ended up with the same value of the monetary base adjusted in June 2011. This would have required Treasury securities held outright by the Fed to expand by about

\footnotetext{
${ }^{24}$ VanHoose (2008) points out that the 2006 law authorizing the payment of interest on reserves requires that the Fed set the interest rate "at a rate or rates not to exceed the general level of short-term interest rates." Clearly the subsidy being paid on reserves exceeds the legal ceiling.
} 
$\$ 225$ billion instead of the actual rise of $\$ 107.6$ billion. Despite the same growth of the monetary base adjusted, Federal Reserve Credit and the total assets of the Fed would have been increased about $\$ 224.6$ billion instead of $\$ 1.943$ trillion, a nearly nine times larger increase in Fed assets. Balance sheet scale has become a newly desired feature of Fed policy. The traditional monetary policy approach of expanding the balance sheet as necessary to boost the monetary base adjusted would have avoided blowing up the balance sheet to provide private credit and creating new taxpayer subsidies for depository and other financial firms, yet without taking on such extreme interest rate risk on long-term Treasuries and default and interest rate risk on long-term private sector assets. This growth of the monetary base was not constrained by a near-zero federal funds rate either; it could only have been constrained by a Fed unwillingness to purchase safe Treasury securities.

\section{A Defense of the Fed}

Nelson (2011) links new Fed practices to central banking theory. He provides five key features of the policy response to the financial crisis that he argues are consistent with Milton Friedman's framework for monetary policy. One of these, a broadening of deposit insurance to reduce systemic risk (runs), may be consistent with Friedman's views because Friedman did make the case for insurance as a way to avoid runs on banks. Whether Friedman would agree that this extension was necessary in the recent recession is another matter. More important for the purposes here, expanding deposit insurance is not a Fed policy action, as Nelson also recognizes. 
A second feature, that commercial banks received assistance through recapitalization, refers to the Troubled Asset Relief Program (TARP), which also was not a Fed response. Nelson argues that Friedman supported assistance to banks by the Reconstruction Finance Corporation in the 1930s and support for Continental Illinois Bank. However, TARP support was not really a recapitalization. It was a provision of liquidity assistance via the purchase of preferred stock and of troubled assets for which warrants were received. ${ }^{25}$ While the preferred stock did qualify as Tier 1 capital, they were equivalent to sales of a long-term debt with a fixed coupon rate, not equivalent to new purchases of equity. This is a well know shortcoming of the Tier 1 concept and measure. TARP aimed explicitly to provide assistance only to solvent institutions. The largest banks were forced to accept the assistance and generally repaid as soon as allowed. In 2008-10, about 325 banks failed, less than one-fourth the total (1412) in 1989-1991, the comparable worst three years of the Savings-and-Loan crisis, and less than one-seventh the total associated with 1981-93 failures (2335).

The three features of the Fed response are, loosely quoting Nelson: (1) An extension of discount lending broadly to the financial system at interest rate below market rates before the crisis, (2) Fed holdings of Treasury securities

\footnotetext{
${ }^{25}$ This may be controversial statement because the Reconstruction Finance Corporation used purchases of preferred stock to "recapitalize" banks in the 1930s and preferred stock is counted as Tier 1 capital. Gertler, Kiyotaki and Queralto (2011) model preferred stock as "inside equity," along with subordinated debt (p. 16), although later they argue that inside equity can only be augmented by retained earnings. They argue that subordinated debt and preferred stock improve bank functioning, an argument that has been made for the signaling function of debt. Their first notion of equivalence with debt is closer to traditional accounting and finance notions of preferred stock, where the stock similarity is based on the perpetual life of common stock, despite its debt feature of a fixed dividend. Preferred stock increases financial risk for firms, unlike common stock. The issue is mute in the case of TARP, however, because the preferred stock largely was repurchased shortly after its issue.
} 
adjusted to lower the path of important interest rates relative to short term rates, and (3) the payment of interest on reserves.

Extending discount lending to non-depository institutions was strongly at odds with Friedman's recommendations. Half a century ago, Milton Friedman recommended that Congress should "Repeal present power of the System to make loans to member banks, to discount paper for them, and to make loans to private individuals, corporations, or non-federal public bodies. This would eliminate any necessity for the System to establish discount rates or eligibility requirements" (1959, p. 100). Friedman was opposed to lending to banks, and more so against other private sector credit. Friedman emphasized that discount lending, if it occurs, should be at a penalty discount rate. Since the 2003 innovations in discount policy, lending was at a fixed penalty. In 2007 the Fed reintroduced a variable rate to encourage borrowing, ending the clarity of the policy adopted earlier. Also, it is not the interest rate relative to the period before a crisis that affects borrowing; it is the rate at any point in time relative to the alternative cost of borrowing at the same point in time. Nelson claims that Friedman advocated a discount rate lower than the rate prevailing before the crisis. In fact Friedman's concern was to use a penalty rate if the central bank undertakes lending, exactly what Bagehot (1873) advocated, though Nelson claims that Fed policy actions and Friedman's policy prescription were counter to Bagehot's Law.

It is difficult to argue that adjustments in holdings of Treasury securities lowered the path of longer term interest rates. From July 2007 until February 2009 (see Figure 3), that is, from well before the recession began until it was almost over and for the first five months following the onset of the financial crisis and 
probably after it was over, the Fed's Treasury security holdings fell. It is hard to argue that these actions lowered interest rates. Moreover, the monetary base adjusted growth slowed over the next year, or more precisely from January 2009 to January 2010.

Friedman was an advocate of paying interest on reserves, but, as discussed above, not a subsidy to private depository institutions that cost $\$ 6.4$ billion, or $\$ 2.6$ billion per year in its first 30 months or so. The authority to pay such interest had nothing to do with the financial crisis. ${ }^{26}$ Also, his efficiency argument for paying interest on reserves applies only to required reserves, not excess reserves, though he did not make that distinction. Congress authorized such payments in 2006 to begin October 2011. The Fed was able to accelerate this plan because of the financial crisis through the Emergency Stabilization Act of 2008, to begin October 2008. So the genesis of the idea and its authorization were completely independent of the crisis. It is the case that the crisis provided a justification for the introduction of the practice to be advanced.

\section{Conclusion}

Chairman Bernanke has asserted: "I grasp the mantle of Milton Friedman. I think we are doing everything Milton Friedman would have us do." See Nelson (2011), based on Chan (2010). Yet, at least four of Nelson's claims of consistency with

\footnotetext{
${ }^{26}$ The Fed's advocacy of paying interest on reserves also had little to do with Friedman's argument about incentives and resource allocation. VanHoose (2008) and Dutkowsky and VanHoose (2011) explain that the principal Fed argument was to reduce sweep balances and that the Fed could do this by setting an interest rate on excess reserves about 4 percent below the bank loan rate, or, alternatively, by significantly reducing reserve requirements.
} 
Friedman are in fact counter to the principles of central banking that he laid out. $^{27}$

What is consistent with Friedman's work is the fact that setting a nominal interest rate target is not sufficient to control the real federal funds rate and his argument that the Fed is the principal cause of recessions. The day after his death, the Wall Street Journal published his last article. Friedman (2006) compared the path of money growth surrounding the Great Depression and the end of stock price bubbles in the early 1990s in Japan and in 2000 in the United States. He showed that cyclical downturns were predicted by slowing money growth and that the cyclical slowing was larger, the larger was the slowing in money growth. The sharp slowing in monetary base growth to an historical low in January 2008 reflects another such instance. Fed policy led to fluctuations in the real federal funds rate and the monetary base that slowed the recovery. During and after the foreclosure crisis, recession and financial crisis the Fed has followed a path that compromised the indicators used to assess policy and

\footnotetext{
${ }^{27}$ One of the most egregious of Nelson's (2011) errors is his claim that "Though he found some beneficial steady-state welfare effects of deflation, Friedman (1969) ultimately concluded against deflation even as a long-run objective." (p.28, ftn.32). As support for his claim, Nelson argues: "There is widespread agreement that keeping expectations of inflation from declining below levels consistent with price stability is desirable under all circumstances." See Nelson (2011, p. 28). This is essentially a defense of the Chairman and FOMC's deflation phobia. Friedman was very clear that the practical policy in both the short run and long run was to select a monetary growth rate to aim for constant factor prices and for final product (goods and services) prices falling at a 2 percent rate. He estimated the money growth rate required to be 2 percent per year. This was a practical adjustment from his estimate of a true optimum of about 4 to 5 percent rate of deflation, or more, for product prices. See Friedman (1969, pp. 45-48, and a repudiation of his earlier 5 percent rule. In no subsequent work did Friedman qualify or reject the superiority of his (1969) 2 percent rule and its deflation objective, nor did he alter the 1969 qualification that the higher price stability result (zero rate of increase in prices of final goods and services) with a 5 percent rate of money growth as no more than an "intermediate" objective that is superior to "current practice."
} 
created serious new risks to the Fed and its ability to function in future. It adopted a credit policy that severed the link of Fed credit and the monetary base, created new subsidies that were costly and ineffective, and inflated the Fed's balance sheet with little or no effect on economic performance. These actions appear to be deliberate, as the Chairman of the Fed has long argued that the real effects of the financial fallout during the Great Depression independently contributed to it severity. In his view, targeted credit provision to distressed firms was the solution. Never mind the principle that failed firms should be closed to minimize effects on creditors, their customers and the economy.

The evidence presented here shows that the Fed slowed the growth of the monetary base to recessionary levels by early 2006 and that it persisted in recessionary monetary base growth up until the beginning of the recession and well into the long recovery, delaying recovery and economic expansion. The evidence also shows that the Fed focused more on expanding private credit rather than expanding the monetary base and it complicated this approach by following a commercial banking model of private credit expansion. To implement this approach the Fed created new liability possibilities to expand excess reserves and supplementary Treasury deposit facilities and it reduced its traditional assets. None of these actions changed overall credit available directly and indirectly from the Fed and banking system to the private sector, but it did allow the expansion of the Fed's balance sheet and reduced credit available through depository institutions. The evidence shows that the explosion in the size of the Fed's balance sheet was not accompanied by effective monetary base 
expansion and therefore was not accompanied by stimulus to generate a typical quick recovery and expansion in economic activity.

In the Fed's response to the financial crisis, furthering its credit policy, it has ended up with more than $\$ 1.5$ trillion of excess reserves that it supports by a huge subsidy to depository institutions. The Fed would find that it is difficult to eliminate these excess reserves, should it desire to do so, because its balance sheet is heavily exposed to illiquid and risky long-term private sector assets and a predominately long duration portfolio of long-term Treasury securities.

Legally, most of the Fed's new credit policy came about under the cover of Section 13 (3) of the Federal Reserve Act. These asset powers should be eliminated or seriously tightened up by the Congress. ${ }^{28}$ Otherwise the Fed will conduct its future business in a similarly opaque, risky, and costly fashion in the next financial crisis, even if in fact it actually eliminates all of these new discretionary facilities and policies temporarily before then. It is well to recall that the shift to the new credit policy began well before the financial crisis, as a

\footnotetext{
${ }^{28}$ Emerson (2010) takes a stronger view, arguing that Fed actions violated their existing authority under Section 13 3. This appears to be an overstatement. In either case, Congress is the only entity that can limit the excesses of the Fed in this regard. The 2010 Dodd-Frank Act specifically prohibits the Fed from ever making loans to insolvent firms. It requires consultation with the Treasury before future Section 13(3) actions can be undertaken, and only for a wide class of borrowers (i.e. not AIG alone). Such consultations were required for bank lending under the Federal Deposit Insurance Corporation Improvement Act of 1991 (FDICIA), but did not restrain the Fed from making loans to failing banks in the recent crisis. Instead the Fed has made it easier for financial institutions to become banks and have access to lender of last resort Fed by taking on bank charters, even though they are not essentially depository institutions. In the earlier case (FDICIA) the consultations required the approval by two-thirds of the FDIC Board, the Board of Governors of the Federal Reserve System and the Secretary of Treasury. At least with that failed precedent, the use of Section 13 (3) lending has not been constrained the Fed. Political economy theory suggests that there is no reason for the Treasury to decline any perceived help from the Fed in providing credit to politically favored parties.
} 
response to the mortgage foreclosure crisis and recession. In addition, the Congress could improve the management of reserves by outlawing the payment of interest on excess reserves, by ending the existing subsidy to banks for holding required reserves by mandating a discounted level of the rate paid on required reserves to a rate somewhat below the lesser of the Treasury bill rate and federal funds rate. Finally, the Congress could restrain the Fed's ability (and the Treasury's complicity) to act as a commercial bank by engineering Treasury deposits at the Fed (matched by artificial increases in Treasury debt) that could accommodate a further expansion of private sector lending by the Fed. 


\section{References}

Aglietta, Michel and Laurence Scialom (2009). "Permanence and Innovation in Central Banking Policy for Financial Stability," in Robert R. Bliss and George G. Kaufman (Eds.), Financial Institutions and Markets. New York: Palgrave Macmillan, pp. 187 - 211.

Andersen, Leonall C. and Denis S. Karnosky (1977). "Some Considerations in the Use of Monetary Aggregates for the Implementation of Monetary Policy," Federal Reserve Bank of St. Louis Review (September), 2 - 7.

Anderson, Richard G. and Robert H. Rasche (1996). “Measuring the Adjusted Monetary Base in an Era of Financial Change," Federal Reserve Bank of St. Louis Review 78 (6), November/December, pp. 3-37.

Bagehot, Walter (1873). Lombard Street: A Description of the Money Market. New York: Charles Scribner's Sons.

Bech, Morten L. and Elizabeth Klee (2011). "The Mechanics of a Graceful Exit: Interest on Reserves and Segmentation in the Federal Funds Market," Journal of Monetary Economics 58, pp. 415-41.

Belongia, Michael T, and Peter N. Ireland (2012). "Quantitative Easing: Interest Rates and Money in the Measurement of Money," Boston College Department of Economics Working Paper 801. 
Bernanke, Ben (2002). “On Milton Friedman's Ninetieth Birthday," a speech presented at the Conference to Honor Milton Friedman, University of Chicago, Chicago, Illinois, November 8. (1983). "Nonmonetary Effects of the Financial Crisis in the Propagation of the Great Depression," American Economic Review, Vol. 73(3), 257-276.

Bernanke, Ben S. and Alan S. Blinder (1988). "Credit, Money, and Aggregate Demand," American Economic Review 78 (May), 435-39. , and (1992). "The Federal Funds Rate and the Channels of Monetary Transmission," American Economic Review 92 (September), 901 - 21.

Bowman, David, Etienne Gagnon and Mike Leahy (2010). “Interest on Excess Reserves as a Monetary Policy Instrument: The Experience of Foreign Central Banks," Board of Governors of the Federal Reserve System, International Finance Discussion Papers, No. 996, March.

Carpenter, Seth B. , Jane E. Ihrig, Elizabeth C. Klee, Daniel W. Quinn and Alexander H. Boote (2013). "The Federal Reserve's Balance Sheet and Earnings: A Primer and Perspectives," Finance and Economic Discussion Series 2013-01, Federal Reserve Board of Governors.

Calomiris, Charles W., Joseph R. Mason and David C. Wheelock (2011), “ Did Doubling Reserve Requirements Cause the Recession of 1937-38," Federal Reserve Bank of St. Louis Working Paper 2011-002-A, January. 
Chadha, Jagjits S., Luisa Corrado and Jack Meaning (2012). "Reserves, Liquidity and Money: An Assessment of Balance Sheet Policies," CEIS Working Paper No. 230.

Chan, Sewell (2010). "Friedman Casts Shadows as Economists Meet," New York Times, November 8, B1, B3.

Dutkowsky, Donald H. and David D. VanHoose (2008)."Interest on Bank Reserves and Optimal Sweeping," Journal of Banking and Finance 35, 2491 - 2497.

Epstein, Gerald and Thomas Ferguson (1984). “Monetary Policy, Loan Liquidation and Industrial Conflict: The Federal Reserve and the Open Market Operations of 1932," Journal of Economic History 44(4), December, pp. 957-983.

Emerson, Mark (2010). "The Illegal Actions of the Federal Reserve: An Analysis of How the Nation's Central Bank Has Acted Outside the Law in Responding to the Current Financial Crisis," William \& Mary Business Law Review, Vol. 1(1), Article 5, http://scholarship.law.wm.edu/wmblr/vol1/iss1/5.

Ford, William F. and Walker F. Todd (2010). "The World's Most Profitable Company," American Institute for Economic Research (AIER), Research Report, November 2, 2010.

Friedman, Ben S. and Kenneth N. Kuttner (1992). “Money, Income Price, and Interest Rates," American Economic Review 82 (June), 472-92.

Friedman, Milton (2006). "Why Money Matters," Wall Street Journal, November 17. 
Friedman, Milton (1969). The Optimum Quantity of Money and Other Essays. Chicago: Aldine Publishing Company.

Friedman, Milton (1959). A Program for Monetary Stability, New York: Fordham University Press.

Friedman, Milton and Anna Jacobson Schwartz (1963). A Monetary History of the United States 1867-1960, Princeton: Princeton University Press.

General Accounting Office (2011). Federal Reserve System: Opportunities Exist to Strengthen Policies and Processes for Managing Emergency Assistance, Report to Congressional Addressees, July.

Gertler, Mark, Nobuhiro Kiyotaki and Albert Queralto (2011). “Financial Crises, Bank Risk Exposure and Government Financial Policy," New York University Working Paper, May.

Giannone, Domenico, Michele Lenza, Huw Pill and Lucrezia Reichlin (2012). "The ECB and the Interbank Market," European Central Bank Working Paper No. 1496, November.

Goodfriend, Marvin (2011). "Central Banking in the Credit Turmoil: An Assessment of Federal Reserve Practices," Journal of Monetary Economics, Vol. 58(1), 1-12.

Hafer, Rik and Scott E. Hein (1984). "Predicting the Money Multiplier: Forecasts from Component and Aggregates Models," Journal of Monetary Economics, November, pp. $375-84$. 
Hetzel, Robert L. (2009). “Monetary Policy in the 2008-09 Recession," Federal Reserve Bank of Richmond Economic Quarterly 9(2), Spring.

Ize, Alain and Nada Oulidi (2009). "Why Do Central Banks Go Weak?," IMF Working Paper 09/13, January.

Joyce, Michael, Ana Lasaosa, Ibrahim Stevens and Matthew Tong (2009). "The Financial Market Impact of Quantitative Easing," Bank of England Working Paper No. 393.

Kashyap, Anil K. and Jeremy C.Stein (2012). "The Optimal Conduct of Monetary Policy with Interest on Reserves," American Economic Journal: Macroeconomics 4(1), pp. 266-82.

Keister, Todd, Antoine Martin, and James McAndrews (2008). “Divorcing Money from Monetary Policy," Federal Reserve Bank of New York FRBNY Economic Policy Review 14(2), September, pp. 41-56.

Klueh, Ulrich H, and Peter Stella (2008). “Central Bank Financial Strength and Policy Performance: An Economic Evaluation," IMF Working Paper 08/176, July.

Leeper, Eric M. and Jennifer E. Roush (2003). “Putting 'M; Back in Monetary Policy," Journal of Money Credit and Banking 35 (December), 1217 - 56.

McCallum, Bennett T. (2000). “Alternative Monetary Rules: A Comparison with Historical Settings for the United States, the United Kingdom, and Japan," Federal Reserve Bank of Richmond Economic Quarterly 86 (1), Winter. 
(1988). "Robustness Properties of a Rule for Monetary Policy," Carnegie-Rochester Conference Series on Public Policy 29, 173 -204.

Meltzer, Allan (2010). “Milton Friedman vs. the Fed," Wall Street Journal, November 4.

(2003). A History of the Federal Reserve System, Volume I: 1913-

1951. Chicago: The University of Chicago Press.

(1987). "Limits of Short-Run Stabilization Policy," Economic Inquiry,25 (January), 1-14.

Nelson, Edward (2011). "Friedman's Monetary Economics in Practice," Board of Governors of the Federal Reserve System Finance and Economics Discussion Series Working Paper 2011-26, April.

Rasche, Robert H. and James M. Johannes (1987). Controlling the Growth of the Money Supply. Rochester Studies in Managerial Economics and Policy, Kluwer Academic Publishers.

Schwartz, Anna (1992), "The Misuse of the Fed's Discount Window," Federal Reserve Bank of St. Louis Review, (September/November), 558-69.

Tatom, John A. (2009). "The U.S. Foreclosure Crisis: A Two-Pronged Assault on the Economy," in Robert R. Bliss and George G. Kaufman (Eds.), Financial Institutions and Markets. New York: Palgrave Macmillan, pp. 131 - 154. (2006). “Money Growth Has Slowed Sharply-Should Anybody Care?” Networks Financial Institute Research Buzz 2(9), November, pp. 1-3. 
Taylor, John B. (2009). Getting Off Track. Hoover Institution Press.

, (1993). "Discretion versus Policy Rules in Practice," Carnegie -

Rochester Conference Series on Public Policy 39, pp. 195 - 214.

VanHoose, David D. (2008). “Interest on Reserves: Implications for Banking and Policymaking," Networks Financial Institute Policy Brief 2008-PB-05, May.

Wheelock, David (2003). "Replacement Windows," Federal Reserve Bank of St. Louis Monetary Trends, May. 